\begin{tabular}{c|cc|}
\hline $\begin{array}{c}\text { ADVANEARCH } \\
\text { ARTICLE }\end{array}$ & $\begin{array}{c}\text { Volume } 6 \mid \text { Issue } 2 \mid \text { December, 2015 | 141-148 } \\
\text { a ISSN-2231-6418 }\end{array}$ \\
\hline DOI: 10.15740/HAS/ARJSS/6.2/141-148 & visit us : www.researchjournal.co.in \\
\hline
\end{tabular}

\title{
Impact of different activities of KVK, Kutch among the date palm growers
}

\author{
Y.V. Patel*, P.V.K. Sasidhar ${ }^{1}$ and K.A. Thakkar ${ }^{2}$ \\ Krishi Vigyan Kendra, Mundra, KUTCH (GUJARAT) INDIA \\ ${ }^{1}$ School of Extension and Development Studies (SOEDS), Indira Gandhi National Open University, NEW DELHI, INDIA \\ ${ }^{2}$ Sardarkrushinagar Dantiwada Agricultural University, SARDARKRUSHINAGAR (GUJARAT) INDIA
}

\begin{tabular}{|c|c|}
\hline ARTICL & \\
\hline Receive & 20.06 .2015 \\
\hline Revised & : 13.10 .2015 \\
\hline Accepted & : 26.10 .2015 \\
\hline
\end{tabular}

KEY WORDS :

KVK, Date palm growers, Impact

HOW TO CITE THIS ARTICLE :

Patel, Y.V., Sasidhar, P.V.K. and Thakkar, K.A. (2015). Impact of different activities of KVK, Kutch among the date palm growers. Adv. Res. J. Soc. Sci., 6 (2) : 141148.

\section{ABSTRACT}

Datepalm is one of the most potential fruit crop for dry arid regions. Kutch district of Gujarat state enjoys monopoly of commercial cultivation of datepalm in India. KVKs are grass root level scientific institution for imparting vocational skill training to the farmers and field-level extension workers, conducting OFT and FLDs on major agricultural technologies. KVK, Kutch was established by ICAR in 1992 at Mundra. Since its inception, KVK, Kutch was carried out numbers of activities for datepalm development in the district. The explicit importance and crucial contribution of KVK activities in datepalm development, the present investigation of impact of KVK activities among the datepalm growers was carried out in major datepalm growing talukas viz., Anjar, Mundra, Mandvi and Bhuj talukas of kutch district. Five villages having highest area under datepalm were selected purposively from each talukas. Two types of respondents' viz., experimental group and control group were selected. For experimental group, village-wise list of those farmers who are benefited by KVK activities was prepared and from this list, 05 datepalm growers from each selected villages were identified by using proportionate random sampling. Thus, total 100 datepalm growers were selected. For control group, similar numbers of those datepalm growers who are not benefited by KVK activities were identified from same selected villages. Thus, 100 such datepalm growers were selected. The experimental research design was used for this study. Major activities carried out by KVK for datepalm development were farmers' trainings $109(3289 *)$, ex-trainees' meetings and group discussion 173(3544*), 291 method demonstrations conducted on offshoot propagation technique on same numbers of farmers' field, 1000 result demonstrations of performance of tissue culture plants of local elite varieties conducted on 22 farmers' field and 62 demonstrations of plastic fruit covering with same numbers of farmers, $289(459 *)$ diagnostic visits on different problems of datepalm growers, $10\left(3496^{*}\right)$ datepalm fruits exhibitions and competitions etc. Regarding the farmers' involvement in KVK activities, more than 80 per cent beneficiary farmers visited KVK more than 10 times and 90 per cent nonbeneficiary farmers visited KVK 0 to 10 times. Regarding their participation, beneficiary farmers participated in frequent guidance of KVK scientists (94\%), datepalm fruits competition and exhibitions (92\%), trainings through KVK scientists (90\%), field visits of KVK scientists $(88 \%)$, seminars and workshops $(82 \%)$ and field demonstrations of KVK (78 \%). The total 24559 farmers were participated / benefited 